Historic, Archive Document

Do not assume content reflects current scientific knowledge, policies, or practices. 



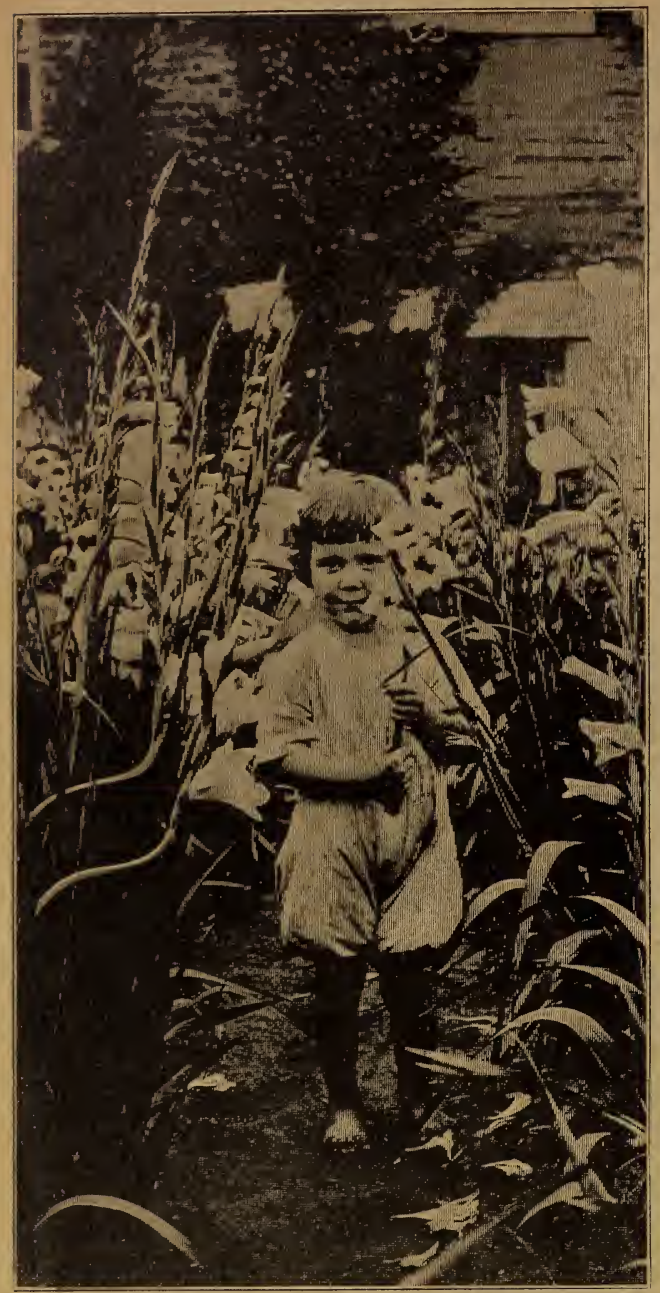

\section{Gladiolus Time}

It is hard to say which is my favorite flower. I like them all. I would hate to do without any of them. But I believe that if I were to be compelled to choose one flower that I would rather have than any other, it would be the Gladiolus.

It is the easiest of all flowers to grow. It is sure to grow and bloom for anyone in any soil and in any part of the country.

It is the only flower that covers the entire rainbow in color. It has every known shade of color. You do not have to wait a year for blooms. It will bloom the same season the bulbs are planted, usually in about 3 months from planting, and will stay in bloom for at least 2 months and often more. Mine began blooming June 15th and will bloom till heavy frost.

They are cheap. You can buy the best of mixtures for from $2 c$ to $3 c$ each, and many of the best named sorts at about the same price A $\$ 2.00$ bill will buy you a whole garde nfull of glorious flowers.

You can "keep your cake and eat it too." for after the bulbs are through blooming you can dig them and put them away and they will bloom better than ever next year, and will in. crease in number and size from year to year.

Now, I suppose you know most of this already, but I just felt like calling your attention to it, because mine are in bloom now, about a million of them and they are the prettiest sight you ever saw. I wish you could all come and see them.

I have every color imaginable and the biggest, fluffiest, most gorgeous lot of flowers you ever saw.

I have oceans of them in mixtures, and then dozens of named sorts, some of them novelties and some of them standard sorts. I am es. pecially pleased so far with Halley, Faust, Niagara, America, Mrs. Frances King, Baron Hulot and Panama, but they are all so nice it is hard to make a choice.

You cannot plant the bulbs till next spring, but you ought to be thinking about it now and figuring on a place to plant them. You could not spend two or three dollars to better advantage.

\section{Fall Bulbs}

Tulips, Hyacinths, Narcissus, and Crocus are all what is known as fall bulbs. This means not that they bloom in the fall, but that they should be set in the fall. They are all early-blooming flowers, blooming as a rule in March, April and May, before other flowers come. They should be set out in October or November, either out-of-doors in garden or in pots for house-blooming. Every year when the tulips and hyacinths are in bloom in the spring we get calls for bulbs from people who want to get them out right away, and they are generally surprised when they find that these bulbs can be bought and set only in the fall. Now, remember, if you want a nice bed of tulips and hyacinths, or narcissus, or crocus, or anything of that kind, you must set them in the fall in October or November. You can, however, send in your order at any time during the spring or summer and we will book it for future shipment. When the proper time comes we will send the bulbs to you.

\section{Will the Dutch Bulbs Get Across}

We think they will. The Hollanders think a lot of their bulb business and they are going to make every effort to fill their contracts.

You know of course that these fall bulbs such as Tulips and Hyacinths all come from Holland, new each year. They are grown for us on contract, the list being made up to two years in advance. We have contracts for a carload of these bulbs to be shipped from Holland in August or September.

Send along your order, and hope for the best, and we will send you the bulbs just as soon as they arrive. If they don't come, we will notify you and return your money. We can take care of you as well as anyone can. 


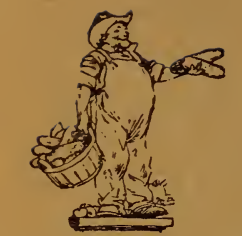

\section{Wholesale Net Prices August 1, 1918}

Good to August 31, 1918 (Subject to stock being unsold)

On Clover, Alfalfa and Other Grass and Field Seeds Which Fluctuate in Price Address all orders to HENRY FIELD SEED CO., Shenandoah, Iowa

We Want Early Orders-So we have made these prices very low considering present conditions and market. We have based them on what the stuff cost us, not on what it would cost us to replace it. We have got the seed in the house, bought right, and up to August 31, (if it lasts that long) we will sell at these prices. When it is gone and we have to buy more at higher prices, you will have to pay more, providing you can get the seed at all. Better buy now while the buying is good.

Write for special quotations after August 31, or send your order and I will fill at lowest possible price.

Time Limit. Note that these prices are good only till August 31, 1918, and if you do not buy in that time you should write fur our new prices. We reserve the right to cancel these prices when stock on hand is sold.

These prices are f. o. b. Shenandoah, customer to pay the freight. If you want delivered prices we will make a special estimate for you on request.

No extra charge for sacks, except for wheat and rye. All other seeds are sold "sacks weighed in." Remember this when comparing prices.

Prices are strictly net, spot cash, and no discount.

Safe arrival guaranteed. Clover and alfalfa seed are generally double sacked, and everything is well packed. We guarantee that all seeds will reach you in good order.

Sold on approval. These seeds are priced and sold with the understanding that if not found perfectly satisfactory they may be returned at our expense

(Every item is extra fancy grade unless specified

Clover and Grass Seed Per Equals

Clover Seed (60 lbs. per bu.) 100 lbs. per bu.

Medium or Common Red

Mammoth Red -

Alsike -

White or Dutch

Sweet Clover (all scarified)

White Biennial _(Melilotus Alba)

White Biennial
hellow Biennial (Melitotus Officin-

alis) hulled (M. 22.00

Ask for prices on unhulled, unscarified and 13.20

Alfalfa (all $d r y$ and northern grown, hardy)

Kansas-Nebraska, first grade_--- $23.23 \quad 14.00$

Kansas-Nebraska, poor but honest_- 13.23 8.00

Dakota grown -

Montana grown

Liscomb, Montana grown

Grimm, Dakota or Colorado Grown_- 50.00

Baltic, Dakota grown

$\mathbf{2 4 . 0 0}$

24.00
30.00

30.00

Timothy and Timothy Mixtures ( All 45 lbs. per bu.)

Timothy, best home grown. 11.00

Timothy-Alsike mixture

Timothy-Red clover mixture--.-- 13.00

Blue Grass (all 14 lbs. per bu.)

Kentucky Blue Grass.- 30.00

English Blue Grass.-.- 20.00

Canadian Blue Grass

Other Grasses

Red Top, fancy solid seed

Red Top, fancy solid seed.-- $--\overline{--} 18.00$

Orchard Grass unhulled or rough seed.- 10.00

Bermuda Grass --

English or Perennial Rye Grass.-- 14.00

Italian Rye Grass

Lawn Grass Mixture-- 30.00

Permanent Meadow Mixture---

Lowland Pasture Mixture

Woodland Pasture Mixture

Forage, Fodder Crops and Grain

Dwarf Essex Rape

Sudan Grass --

Cane or Sorghum (all $\mathbf{5 0}$ lbs. per bu.)

Fodder cane, Amber type

Fodder cane, Orange type-_.-- 8.00 and your money will be refunded. You can be the judge of quality.

One grade only. We quote on one grade only, a high grade. We do not believe in low grades, and do not wish to encourage the use of them. Good seed is the cheapest in the long run.

Reference. First National Bank of Shenandoah, Ia.

Free Samples. We will gladly send free samples of any kind of seed quoted here.

Subject to Sale. All prices are subject to stock being unsold on receipt of order.

YOUR MONEY'S WORTH OR YOUR MONEY BACK

It is mutually agreed and understood that any seeds or other goods ordered of us may be returned at any time within ten days after receipt if not satisfactory and money paid for them will be refunded, but we do not and cannot, in any way, warrant the crop, as it is dependent on so many conditions beyond our control. HENRY FIELD SEED CO.

otherwise.)

\section{Small Grain}

$\begin{array}{lr}\text { Winter Rye-Common } & \text { per bu. } \\ \text { "\# } & 2.50 \\ \text { Winter Wheat-Turkey Red and } 404 & 2.75 \\ \end{array}$

Bags are extra on wheat and rye at $60 \mathrm{c}$ for white and $4 \mathrm{Cc}$ for burlaps holding $2 \mathrm{bu}$. to $21 / 2$ bu. each.

Millet (50 lbs. per bu.)

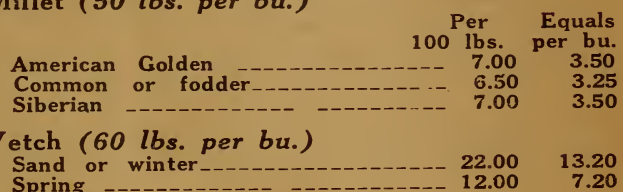

Field Peas (60 lbs. per bu.)

Whipporwill Cow Peas $6.00 \quad 3.60$

4.95 New Era Cow Peas

5.40 Nixed Cow Peas $\quad$ Mew Era Cow Peas

$\begin{array}{lllll}5.85 & \text { Mixed Cow Peas } & \\ & \text { Canadian or Northern }\end{array}$

4.20 Soy Beans (60 lbs. per bu.)

$\begin{array}{lllll}2.80 & \text { Medium Yellow } & & \\ & \text { Mongol } & & \end{array}$

$\begin{array}{llll}2.80 & \text { Mongol } & \end{array}$

Extra Early Black

$\begin{array}{llll}2.52 & \text { Extra Early Black._- }\end{array}$

3.92 Large Black -

Morse

1.96 Field Beans (prices for large lots)

White Navy

Great Northern (large white field) $18.00 \quad 10.80$

Pinto (Colorado brown striped field) $15.00 \quad 9.00$

Tepary (dry landers)

Bunch Blackeye _..- $16.00 \quad 9.60$

Broadcast Seeders

Cyclone, each

$\$ 1.50$

4.00 Little Wonder, each

These are wholesale prices, good for amounts of 10 pounds of a kind, or over. Add $2 \mathrm{c}$ per pound for amounts of 5 to 10 pounds. Add $5 \mathrm{c}$ per pound for amounts below 5 pounds. 


\section{ORDER SHEET}

Date

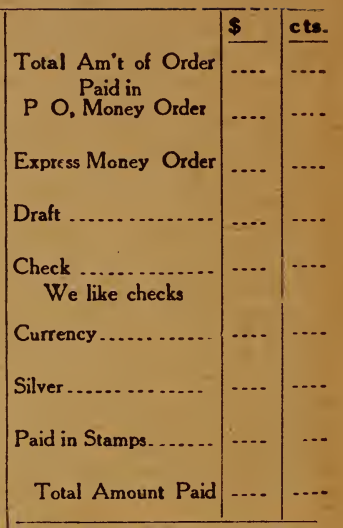

\section{To HENRY FIELD SEED CO., Shenandoah, lowa}

Name ...

Postoffice

State

County Rt. No.

Box

Street and No.

R. R. Station

(Name of town if different from postoffice.)

State

What Railroad?

What Express Co.? (Into Your Town?)

Mark in Square Which Way

You Want Order Sent

\section{Mail or \\ Mail or}

Express (Into Your Town?)

In Case Price Is Wrong or Price Has Changed:--:

Shall we fill exact amount ordered and adjust price later?

Freight

Whatever

Or shall we

fill exactly the amount of money sent?

If out of the variety ordered do we have

your permission to substitute equal or better in the nearest we can supply?

Please Answer Above Information Each Time You Write

Your Money's Wor th or Your Money Back-It is mutually agreed and understood that any seeds or other goods ordered of us may be returned at any time within ten days after receipt, if not satisfactory, and money paid for them will be refunded, but we do not and can not in any way warrant the stand or the crop. as they depend on so many conditions beyond our control. Henry Field Seed Co.

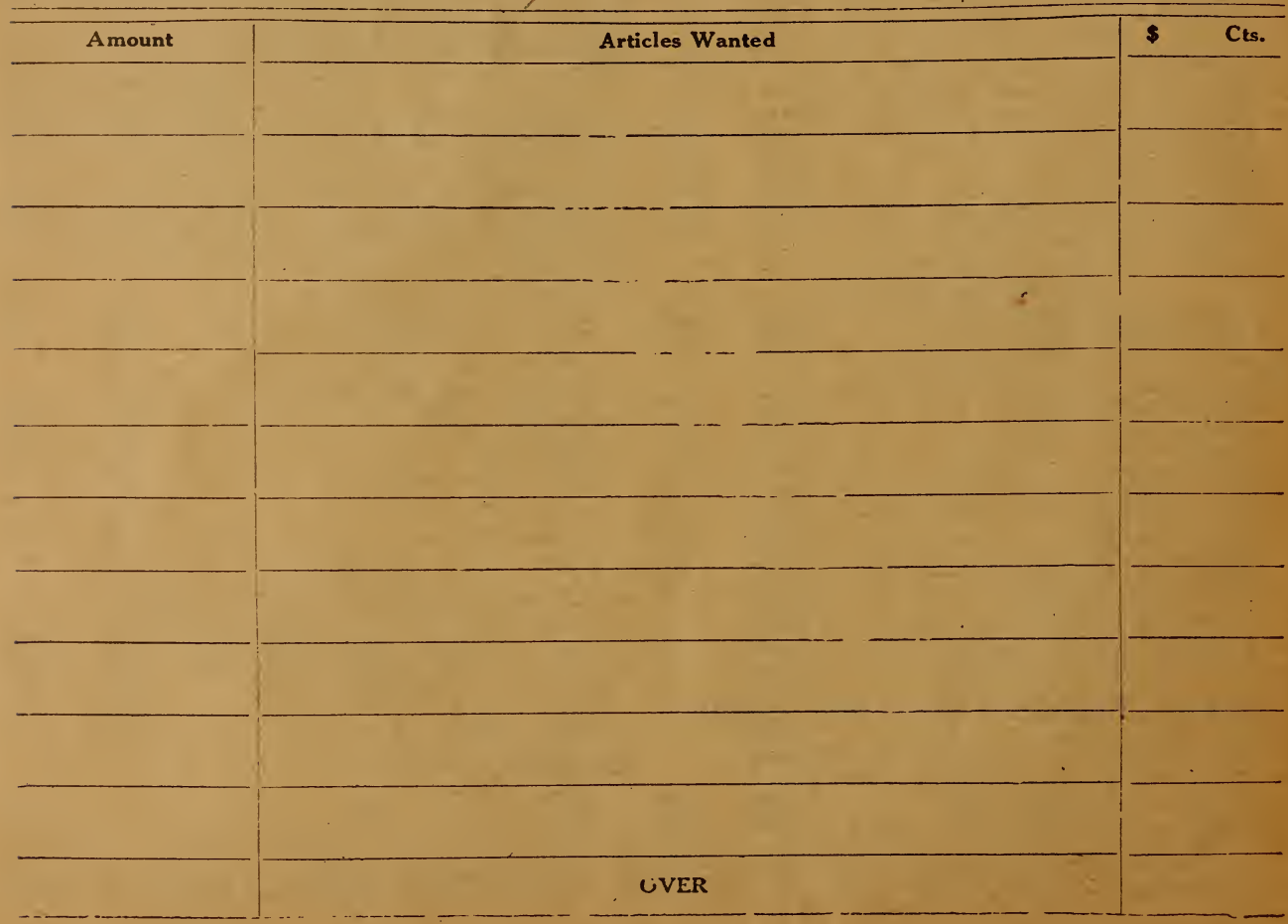




\section{Why Not Plant Alfalfa?}

You know, it is the greatest of puzzles to me why more farmers do not grow alfalfa. Seems to me every farmer ought to grow it. Why not? It is as easy to get started as common clover, and generally easier. It will last for years, and always make a crop. Dry weather does not affect it, and it is not as likely to winter kill as common clover.

This was all brought forcibly to my mind by the following clipping from a recent issue of the Shenandoah Sentinel-Post:

\section{Feed For Stock bos Scarce}

The farmers with a lot of cattle and horses are up against a real proposition for the want of feed. The pastures in many places are as dry as a bone, the hay crop is mighty light and what to feed the stock on is a perplexing question.

A Page county farmer told us the other day that from twelve acres of meadow he only harvested four big loads of hay which amounted to about four tons. It ought to have yielded fifteen tons anyway. The hay crop is very light as a general thing. Farmers will have to utilize every bit of straw they have and cut up a lot of corn in order to get feed for their stock.

Twelve acres of good meadow (probably timothy and clover) and only 4 tons of hay. All right, now here's the other side of it:

On the Mitchell 40 near Manti which I bought last spring there is a 2 acre patch of alfalfa put out by the renter two or three years ago. Fairly good alfalfa, but nothing special. Rather thin dry side hill land. From this 2 acres I cut, at the first cutting about June 1st, 4 very large loads of hay, probably 5 tons. Then I turned the hogs in to pasture it the rest of the season, 33 good sized shotes and 2 old sows, and they went after it in great shape. They could not keep it down however, and on July 1st I hauled to the barn 2 big loads of hay from second cutting, besides all the hogs had eaten.

That makes about 7 tons of hay so far from that 2 acres, with a good chance of 3 or 4 more from the other two cuttings to come yet, and a big lot of pork in the pasturing. I am not worrying about either hay or pasture. And you don't need to either.

Of course it is too late for this year, but you can get fixed for next year. I am sowing alfalfa seed in the corn right now, and if we get any rain at all, I will have a fine growth of alfalfa by fall, and a good field for hay or pasture next spring.

Greatest thing for hog pasture you ever saw. I have some first of April pigs that weigh nearly 100 lbs. right now, and it's mostly alfalfa. Alfalfa pasture now, and alfalfa hay earlier in the spring. Of course some corn and tankage too, but mostly the alfalfa.

I am sowing the alfalfa seed broadcast in the corn, behind the cultivator, and depending on the rain to wash it into the gorund. If you don't want to do that, you can sow on oats or wheat stubble in September or August if you will get busy right away and disk it up, and then keep it worked well for a month or six weeks

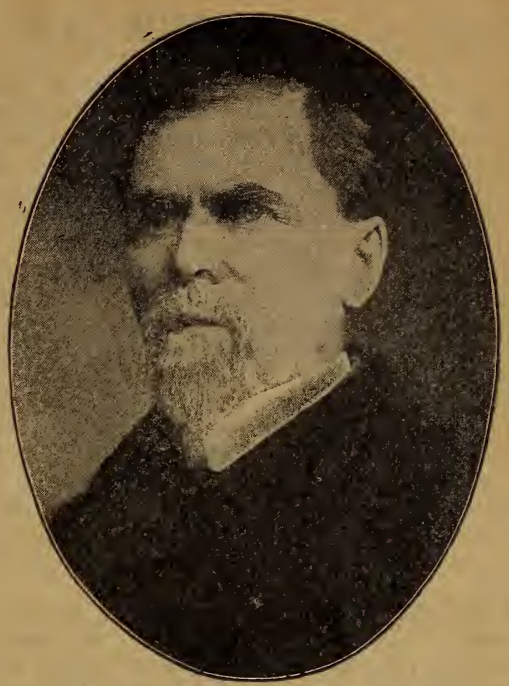

F. D. Coburn, the man who made Kansas rich by boosting alfalfa

\section{Alfalfa}

I am convinced that most of the farmers of the United States are missing a good thing by not growing alfalfa. In some sections it is grown heavily, but in nine-tenths of the country it is hardly known. I have been trying it here and watching it on the farms of my neighbors and I have had a great deal of correspondence with customers in other states who have tried it and I have come to the conclusion that there is hardly a locality in the country where it cannot be grown. As I wanted to give my people the best possible information on this subject, I prevailed on Secretary Coburn, of Kansas, to write an article especially for me. This article is worth $\$ 50$ to any man who will follow it up. Ask for it. I have published it in pamphlet form and will be glad to send extra copies on request.

\section{Where It Is Grown}

In buying alfalfa seed it is important to know where it was grown. For the corn belt we prefer and use Kansas and Nebraska seed. For the north we have Dakota and Montana seed. We don't use southern or far western seed.

\section{Northern Grown Alfalfa Seed}

My alfalfa seed is all northern-grown and non-irrigated and hardy. It is suitable for use anywhere that alfalfa can be grown at all.

till it gets well settled. I like the corn ground idea however.

But whatever you do, don't get caught next year without alfalfa and no hay or pasture. There's no need of it. I suppose I ought to feel: sorry for the man who has no pasture and only 4 tons of hay on 12 acres, but really it's mostly: bis own fault.
HENRY FIELD. 


\section{Sudan Grass for Milk Cows}

To the Editor:- "In the discovery of Sudan grass the bureau of plant and seed introduction of the United States Department of Agriculture, Washington, has made a ten strike. It is a heavy yielder of good to prime hay, a drouth resister and a fine pasture plant that is safe for ruminants.

"Small acreages devoted to grazing last year gave most promising results. Yields of forage high in protein resulted and no cases of bloat such as happens from alfalfa or poisoning, such as comes with cane and kaffir, have been reported. As it belongs to the cane family, it may be that under exceptional conditions, such as the dry weather of 1913, it may prove unsafe, but reports from the Dodge City Experiment Station, where it was under observation and use during 1913, do not mention any trouble in grazing Sudan grass the past three years.

'Supt. W. M. Kirkpatrick, says concerning this new forage: "As shown by experiments here, it is perfectly safe to pasture Sudan grass. The experiments conducted by Mr. Turner the last three years have not shown any harm to stock turned on it at different times of the year.'

"The value of the grass for pasture is shown by the fact that six milk cows turned on the grass September 14th and taken off September 22nd, made an average gain of 48 pounds of milk per head, during the eight days."-W. E. Blackburn, in Farmer \& Stockman.

\section{Get Ready for Alfalfa}

It is a safe guess that at least two-thirds of the alfalfa seed that is sown in the cornbelt is sown in the months of July, August and September, the most of it during the month of August. This is a good time to sow alfalfa. The only thing to remember is to have the ground in first class condition. Most of the failures in growing alfalfa are due to the poor preparation of the soil before the seed is sown. Remember that alfalfa does not catch well on freshly plowed ground. It should be plowed and then worked from two to four weeks, if possible, in order to get the ground settled and in good condition. If possible, you should begin getting the ground ready now, although you can, of course, put the alfalfa in following a crop of wheat or oats, if you will plow the ground just as soon as the grain is off, and work it and get it down in shape.

Remember that we have the very finest alfalfa seed for sale and will be glad to fix you out. Our seed is all sold subject to your own test and approval and subject to the test and approval of any state college or experiment sta. tion. We do not handle imported seed nor low grade native seed. We have the finest quality of native American seed. I can ship you seed from Nebraska, Kansas, Dakota, or Montana, whichever you prefer. We will tell you exactly where the seed came from and tell you the truth about it. We will guarantee our seed free from dangerous weeds or adulterations of any kind. The market on alfalfa seed is advancing.

\section{Alfalfa Seed Crop}

A northeastern Missouri correspondent writes: "What crop of alfalfa do you get seed from? I have seen lots written about alfalfa but nothing about the seed."

In the average year conditions are not $\mathrm{fa}_{2}$ vorable over the greater part of the corn belt for alfalfa seed production. We have too much moisture. In 1914 or 1913, however, a few farmers in Iowa and Illinois secured a good crop of alfalfa seed. For the production of alfalfa seed there should be a fair amount of moisture up to the time of flowering, but not enough to produce a very rank growth. From blooming time on the weather should be hot and dry with barely enough moisture to cause the seed to fill out in good shape. Since the hot, dry weather so favorable to seed production is most likely to come in late July or early August it is customary to leave the second crop of alfalfa for seed. In some sections where they get four crops a year the third crop is left for seed. It is generally reckoned that by taking a crop of seed two hay crops are lost.

In a season like this there is scarcely any one in the corn belt who should consider rais. ing a seed crop of alfalfa. Our weather has been too cool and moist. Even in western Kansas and Nebraska there are considerable areas where the weather has been too cool and moist for the most profitable production of alfalfa seed. Those of our readers who are in. terested in alfalfa seed production should send to the United States Department of Agriculture, Washington, D. C., for Farmers' Bulletin 495.

\section{Good Alfalfa Seed}

Sixteen Samples From Ten Leading Seedhouses and Ours the Best

"I have tested 16 samples of alfalfa seed sent out by 10 of the leading seed companies and the sample which seemed to me to be the most satisfactory was that furnished by the Henry Field Seed grew and I found no bad seeds in it.

This is a pretty good old world after all. Sometimes I get discouraged because farmers will write in and tell me I am asking too much for my alfalfa seed and that they can buy it cheaper elsewhere, and so on. They can't realize that I ask more for my seed because it's worth more. They think it's all alike and I'm holding them up. But when I get a report like the one above, it means something to me. This came from one of the most noted County Advisors in the country. I didn't even know he had a sample of my alfalfa seed. But he had been making a quiet hunt for good seed for the farmers of his county and this is his report to them. It went out to every farmer who is a member of the association in that county. I don't dare give his name or the name of the county, for those men don't like to be quoted on a matter of this kind. It gets them in bad with other seedhouses, but it's the Gospel truth just the same and you may be sure I appreciate it.

If that kind of seed is good enough for you, just help yourself. 


\section{The Alfalfa Seed Bed}

Success in starting alfalfa depends largely upon the preparation of the seed bed. A poor seed bed has been responsible for more failures with this crop than any other one factor. A good seed bed is firm, well settled, not too hard, and with the surface soil mellow and finely pulverized as deep as the seed is to be sown A firm seed bed of this character allows free movement of the capillary water from the subsoil, and at the same time furnishes the plant with the proper root hold. Moisture is not available for the young alfalfa plant in a deep, loose subsoil, for the loose soil prevents the rise of the capillary water. Besides being mellow and firm at planting time, the seed bed should contain ample moisture and available plant food. Time is required to store moisture and to liberate plant food, hence the earlier the preparation of the seed bed can begin, the better will be the results.

A very satisfactory bed for fall seeding may be prepared by shallow-plowing wheat or spring-grain stubble immediately after harvest and working the ground sufficiently thereafter to kill all weeds and maintain the soil in good tilth until seeding time. The plowing should be as shallow as possible and cover the stubble well; otherwise, unless heavy rains come between plowing and planting time, it would be impossible to establish a firm seed bed. It takes several months' time and considerable rainfall to re-firm a deeply plowed soil. Where it is advisable to loosen up the soil to a considerable depth before seeding, the ground should be plowed deeply for the crop preceding alfalfa. A clean field of wheat, oats or barley stubble can be put into good seed-bed condition by disking under the stubble thoroughly soon after the crop has been taken from the land and then keeping it well tilled until planting time. Likewise, in favorable seasons, alfalfa may be successfully fall-seeded after a crop of cowpeas, flax or millet, by disking the ground thoroughly as soon as possible after the crop is removed and keeping it well worked until time to plant.

When alfalfa is to be seeded in the spring, the best seed bed can be prepared by plowing the ground the fall preceding, leaving it rough over winter, and then working it into good conition with the disk and harrow. A fair seed bed can often be prepared in the spring simply by disking corn-stubble land, especially where the corn was kept well cultivated and free from weeds during its growth. When such land can not be fall plowed, this method is to be preferred to spring plowing.

Another satisfactory method of preparing a seed bed, and one that is adapted to land deficient in available plant food, or to parts of the state where conditions are too dry to start alfalfa readily, is to plow the land in the fall or spring and cultivate it sufficiently thereafter to kill the weeds and maintain a soil mulch. The alfalfa may be seeded late in the spring, choosing a time after. a rain when the soil is moist and weather conditions favorable; or the land may be cultivated throughout the summer and the alfalfa seeded in the fall. Soil that is kept fallow and well tilled throughout a long period of time accumulates an extra supply of available plant food and an abundance of moisture. With favorable weather conditions thereafter, a satisfactory stand of alfalfa will be secured on soil on which difficulty ordinarily is experienced in starting the crop.-Bulletin 197, Kansas Experiment Station.

\section{What To Do With the Sudan Grass}

I am getting lots of letters from customers about the Sudan grass. It is doing fine and they are all greatly excited about it. I don't blame them either, for its the prettiest crop growing I ever saw, and is going to be the greatest money maker of all farm crops. That may sound strong, but wait and see.

Just now what is worrying some of them, is when to cut it for hay. My advise would be to cut it as soon as the heads begin to feather out. It is matured enough to make good hay then, and tall enough so you can handle it with a corn binder and short enough so you can handle it with a mower or a binder or a scythe. It will cure easilly, easier than any other fodder.

It really does not matter though just when it is cut, as it does not take harm by getting old. The stems may get a little tough, but the leaves stay green and tender all summer, and there are new tender shoots coming up all the time, whether it is cut off or not. Last summer we left ours stand for seed and did not cut it at all until late in the fall, and although the seed. was ripe, the fodder was green and nice and the stock ate every bit of it.

If you want a seed crop, you can do as we did, let it stand till danger of hard frost and cut it then and save seed and fodder both. Or if your season is fairly long and you got an early start, you can cut it for seed about a month after it first heads out, and then get a hay crop after that. Or you can cut a hay crop when it first heads, and get a seed crop after that.

No one knows just what is the best way to handle it, and the best plan is to do some experimenting this year so you will know better what to do next year.

\section{Fall Seeding of Sweet Clover}

An Illinois subscriber writes: "I would like to sow about ten acres of sweet clover this fall in the corn after the corn is laid by.. When will be the best time to sow? How much would you sow to the acre? Will the sweet clover seeded at this time make good pasture next spring and summer? Would there be any danger of it freezing out this fall and winter?

We do not advise sowing sweet clover in the fall. It is much better to wait until spring and sow with small grain in the same way as red clover is sown. A few of our readers have sown sweet clover in the corn at the last cultivation and have secured a fair stand. The results on the whole, however, have not been so satisfactory as when the sweet clover is seeded in the spring with small grain. 


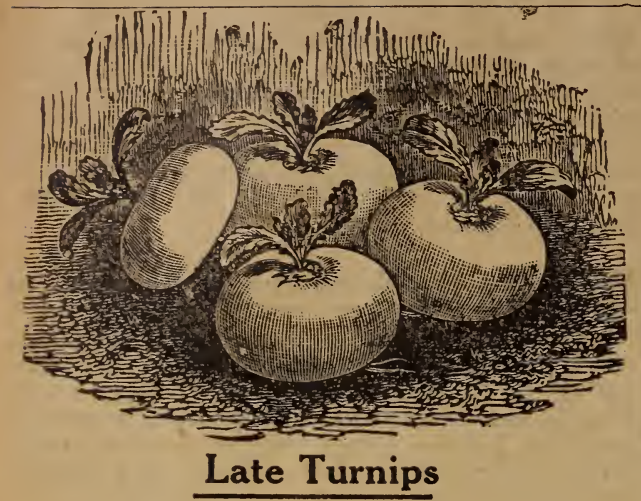

Late turnips should be planted in July and August. Use from one to three pounds of seed to the acre. Broadcasting is a very satisfactory way of sowing, but be careful and don't get too much seed on and see that it is evenly distributed.

Each plant should have a square foot of ground. If you drill them, space the rows about fifteen inches apart and use an ounce of seed to two or three hundred yards of row.

For main crop, and especially for fall sowing, the main standby is the old-fashioned Purple Top Strap Leaf. Large, sweet and fine grain. The Purple Top Globe is practically the same turnip, but slightly deeper in shape and a little heavier. On account of its shape it yields better than the old flat type. White Globe is much like Purple Top Globe, except that it is white and somewhat later. There is also a yellow-fleshed turnip called Amber Globe, but I do not like it so well as the ordinary varieties.

The Rutabaga is a different growing turnip entirely. It has smooth leaves like a cabbage, grows slower than an ordinary turnip and much larger. The best variety has a purple top with a yellow flesh. This is the variety we use. They are not much of a success here in Iowa, but in the northern states they are quite valuable. Postpaid Prices

Amber Globe Postpaid Prices

Purple Top Strap Leaf.--05

Purple Top Globe

Rutabaga

White Globe -

$\begin{array}{lll}15 & 50 & 1.75\end{array}$

$\begin{array}{lll}20 & 55 & 2.00\end{array}$

$\begin{array}{lll}20 & 70 & 2.50\end{array}$

$\begin{array}{lll}20 & 70 & 2.50\end{array}$

$\begin{array}{lll}20 & 55 & 2.00\end{array}$

\section{Rape}

Rape furnishes splendid pasture the same year it is seeded. That is all it is good for. The stockman who is short on pasture is the only one who has any use for it. The hogman appreciates rape most. The sheepman also likes rape, but is not quite so enthusiastic, be. cause rape sometimes causes bloat. Rape makes good pasture for cattle, but the cattle injure it by tramping and, unless care is taken, there is a chance of rape causing bloat and also a taint in the milk of dairy cows. For hogs, therefore, rape is splendid, for sheep it is good and for cattle and horses it is fair.

Sow rape at any time of year, from early spring until the first of August. Begin pasturing it when it is two months old, or fourteen inches high. In buying seed, be sure to get the Dwarf Essex variety. There are several other sorts, with seed just about like the Dwarf Essex, which flower the same year they are grown and are worth not more than half as much. Sow at the rate of four to six pounds per acre. If you are intending to hog or sheep down corn, by all means, broadcast four to five pounds of rape seed per acre at the time of the last cultivation. If you wish to economize in seed you might put the rape in with a single horse wheat drill.

Rape pasture is richer than almost any other pasture, alfalfa and clover not excepted. Some animals do not relish it at first, but generally they soon learn to like it. Rape furnishes the cheapest and best of all the temporary hog and sheep pastures. There should be twice as much rape grown as at present on the stock farms of the corn belt. However, it is only a temporary substitute for alfalfa or clover pastures.-Wallace's Farmer.

\section{How Many Seeds in an Ounce?}

I have been asked hundreds of times how many seeds of different kinds there would be in an ounce or pound or quart and so on. Really, I never could tell absolutely, but one day lately, when some of the girls had some spare time, I had them count up an ounce each of a lot of different kinds of seeds, so we would know exactly how they figured out. Here is the result. It is interesting.

$1 \mathrm{oz}$. Asparagus.--_.-- 1140

1 oz. Bean, Ling Lima_-.. 28

1 oz. Bean, Extra Early Lima

1 oz. Bean, Field's First Early-_- 79

1 oz. Beets

1 oz. Cabbage -

1 oz. Carrots -

1 oz. Celery -

1 oz. Cucumber.

1 oz. Egg Plant_-.

1 oz. Lettuce -

1 oz. Muskmelon, large seed.-- 878

1 oz. Muskmelon, small seed...

1 oz. Mustard -

1 oz. Onions -

1 oz. Parsnips -

1 oz. Pea, Imperial Extra Early---------- 160

1 oz. Pea, Dwarf Champion_-_-_-_-_ 141

1 oz. Peppers -.. 3296

1 oz. Popcorn, Baby Golden.--_-_----- 448

1 oz. Popcorn, White Rice_-_._-_-_-_ 272

1 oz. Pumpkin, Yankee Field....... 157

1 oz. Radish -..- 2396

1 oz. Rhubarb -.. 1664

1 oz. Spinach _... 2150

1 oz. Salsify -- --

1 oz. Squash, White Bush_._._._.___- 297

1 oz. Squash, Hubbard _.......... 155

1 oz. Sweet Corn, Stowell's........ 100

1 oz. Sweet Corn, White Mex........... 121

$1 \mathrm{oz}$. Tomato _......... 640

1 oz. Turnips

1 oz. Watermelon, small seed............ 231

1 oz. Watermelon, large seed............ 221

1 oz. Watermelon, Princess _......... 567

1 qt. Onion Sets, hazelnut size........... 124

1 qt. Onion Sets, pea size............... 346

Better file this away for future reference. 


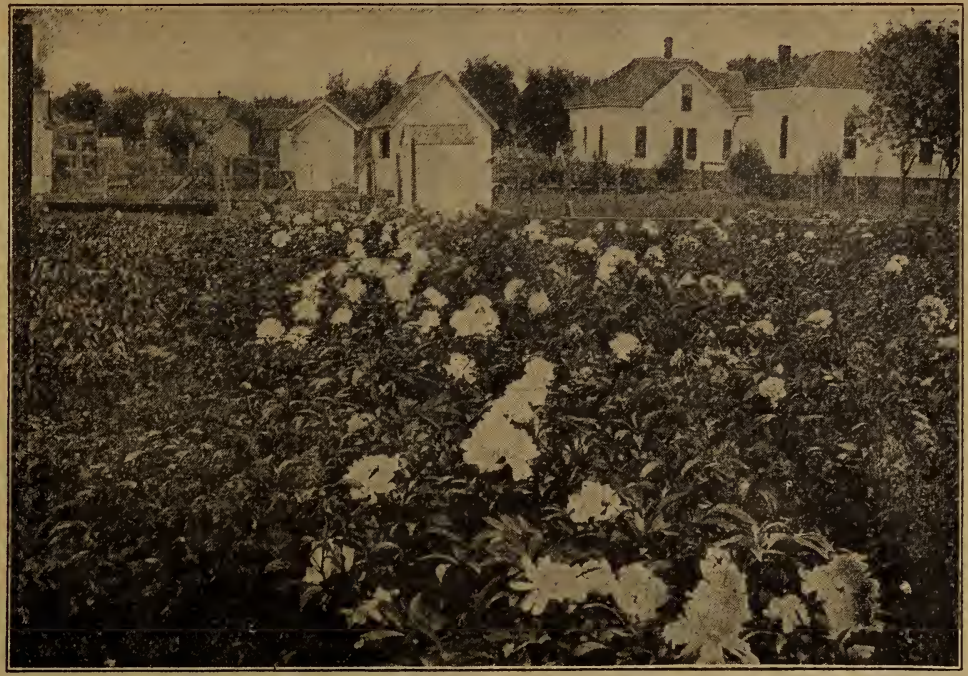

Plant Peonies This Fall

Of course you can plant peonies in the spring if you want to. There is no law against it. But if you really want'to have success with peonies, the time to plant them is in the fall, especially in September and October. They are practically certain then to live and bloom and they will be pretty sure to bloom next spring, too, which would not likely be the case if planted next spring.

I don't know of any flower more satisfacory to plant than peonies. They are sure to live and grow, they will bloom anywhere and for any one and they live forever, getting better with age. They have no disease and no insect enemies, they are big, beautiful and fragrant. They bloom in time for Memorial day. A single clump of them on the lawn is a beautiful sight and a big bed of them is finer yet.

Just notice the picture above showing mine in bloom at the seed house. Did you ever see anything finer? I have probably the finest collection in the country. They are worth coming hundreds of miles to see. I have the varieties that bloom and bloom every year. I can give you any color you want. If you love peonies

\section{Grow My Own Peonies}

I grow my own peonies right here on the seed house grounds, where I can see them every day. In the spring and summer, I pretty near live with them and I know every variety and almost every plant by heart. I know absolutely that thesy are true to name, true to color, healthy and vigorous. You need fear no disappointment when you get peonies out of such a garden as mine. If you buy any peonies from me, or if you have bought any in the past and they are untrue to name or fail to live, I will at any time replace them free.

I have over 200 named sorts, the very finest, at from $25 \mathrm{c}$ to $\$ 1.00$ each. Send along your order. let me fix you out with a start of really good varieties. You will frnd a long list of them in the catalog and in the last September Seed Sense. Study over the list. Besides I have over 200 kinds not listed there. I can give you any kind you want. Considering what you get for your money there is no flower so cheap as peonies. You can buy them from 20c up, for good plants. Anyone can afford to plant them, get them from some neighbor, but by all means plant some.

I never felt that money spent in flowers was wasted. It is money well spent, for there is nothing that gives so much pleasure and happiness in the world. Some one has said that the peony is the flower for the million and for the millionaire. The millionaire could buy nothing finer and the millions can all afford to buy them. And I guess that's about right.

If you have been promising the wife some flowers to fix up the front yard, now is the time for you to make good, by spending a few dollars for the looks of the place, to say nothing of the pleasure it will give the wife and the girls.

\section{Special Offer}

Double White. Mixture of the best large double white varieties. $20 \mathrm{c}$ each, 5 for $\$ 1.00$. Double Pink. A collection of pink sorts ranging from a light shell pink almost to crimson. 20 c each, 5 for $\$ 1.00$.

Double Red. Various shades of deep red. 20c each, 5 for $\$ 1.00$.

Mixed Double. All colors. Hardly any two alike. 20c each, 3 for $50 c, 6$ for $\$ 1.00$, 12 for $\$ 2.00$.

\section{Postpaid}

These prices include delivery by parcels post, all charges prepaid. Remember this when comparing prices. 


\section{Field's Seed Sense}

FOR THE MAN BEHIND THE HOE

\section{Published Monthly by the \\ Henry Field Seed Company}

And Printed in Their Own Private Printshop

Henry Field, Editor E. F. Vincent, Mng. Editor

SUBSCRIPTION PRICE 25c per year or 5 years for $\$ 1.00$.

\section{Another Prosperous Year}

Of course you are all interested in the prosperity and progress of the Henry Field $\mathrm{Co}_{\text {., }}$ for I feel that you are a part of it, and you will be glad to know that we smashed all records this year. It is you that have built it up and made it possible. And it is you that will keep it going.

We have always been fairly prosperousany business that is fair, honest, conservative and built on the right principles, is bound to be. We have never got rich out of it, for we have only drawn a good living out of it and put the rest back into the business. I own half the business and some of my close friends and employees the other half.

We all believe in the simple life, fair profits, liberal dealing and a share of the profits to the workers. We pay bigger wages, give shorter hours, and have better working conditions, than most similar institutions. We give labor dividends and free life insurance and all such. And we are growing faster, have nicer customers, and better suited ones than any seed house I know of. We believe any business attracts its own kind. I believe in keeping every one happy, comfortable, healthy and at workour help, our customers, our neighbors, the family and myself.

I am 46, and a grandfather, and have to wear glasses to read with, but I don't feel old and don't believe I ever will. My father is 84 and as young as ever.

So don't feel that you are dealing with some intangible "company" when you send an order. You are dealing with Henry Field and a bunch of his friends who are the same sort of people.

This year's business has been by far the largest ever. Here is the comparison by years, showing the number of orders and the total sales each year for the past six years.

$\begin{array}{llr}\text { Year } & \text { Orders } & \text { Amount } \\ 1913 & 60,804 & \$ 170,973.09 \\ 1914 & 82,628 & 241,486.13 \\ 1915 & 105,122 & 313,373.12 \\ 1916 . & 133,652 & 412,912.29 \\ 1917 & 204,773 & 631,206.74 \\ 1918 & 218,063 & 1,115,962.14\end{array}$

Total payroll for the year was $\$ 156,959.06$, or an average of about $\$ 3,000$ per week. It was much more than this however during the busy time of early spring; often going to over $\$ 6,000$ for a single week's wages.

The largest number of people on the payroll at any one time was one week in March when it

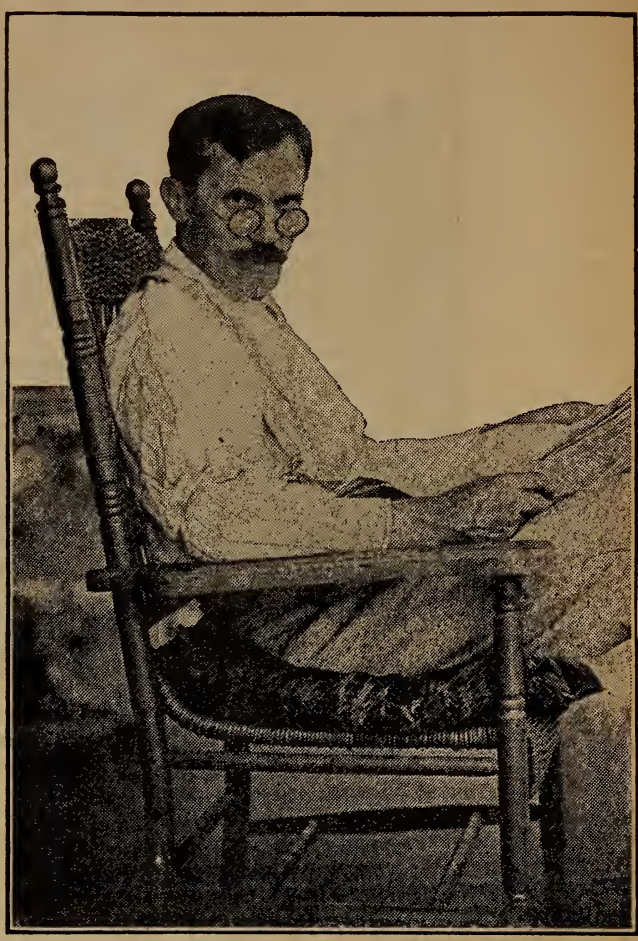

Yes, I have had to begin wearing glasses to read with, but then I am 46 and a grandfather so suppose I ought not to kick.

showed a total of 419 people on the job-173 men and 246 women and girls.

The Labor Dividend was paid as usual, being fixed at a certain percentage of the net earnings for the year. The amount was $\$ 4,699.03$ which was divided pro-rata among all the employees of the company whose wages had amounted to $\$ 150$ or over. It was divided in proportion to the wages each had earned, and went to 283 people in varying amounts. It amounted to the equivalent of about two weeks' pay. This distribution of a percentage of the earnings among the employees has been followed for several years, and it is the intention of the company to keep it up every year if possible.

The earnings for this year were cut quite heavily by the large amount of government taxes of various sorts, amounting to about $\$ 25,000$ in all. The direct taxes in the form of income and profit taxes amounted to $\$ 12,182.39$. Then there was a heavy increase on postage and a tax on freight and express, both of which run into large sums.

The postage bill for the year was $\$ 78,827.37$, which is more than the total postage account of many good sized cities, and is probably two or three times as much as the balance of Shenandoah put together.

All of the old directors and officers were reelected for the ensuing year, and the usual dividend declared, the balance of the earnings after paying the labor dividend, being turned back into the business. Henry Field. 


Standard Inoculating Bacteria
Hastens Maturity
Builds up the Land Encreases the Yield
Improves the Feeding Value Soil
EASY TO APPLY

Simply Moisten the Seed Before Sowing Full Directions in Every Package PREPARED FOR

$\begin{array}{ll}\text { Alfalfa } & \text { Sweet Clover } \\ \text { Soy Beans } & \text { Red Clover } \\ \text { Cow Peas } & \text { Alsike Clover } \\ \text { Field Beans } & \text { Crimson Clover } \\ \text { Navy Beans } & \text { Vetch Peas } \\ \text { Canada Peas } & \text { Sweet Peas } \\ \text { Garden Peas } & \text { Garden Peas } \\ & \text { PRICE: }\end{array}$

Garden size

1 -acre size

2-acre size

4-acre size

6-acre size

\section{By Mail 5c Extra}

\section{Special Notice}

When ordering state Crop to be Inoculated as there is a different Bacteria for each Legume Applied Direct to the Seed

\section{Directions In Each Package}

A 1-acre package of Inoculating Bacteria will inoculate $11 / 2 \mathrm{bu}$. ( $90 \mathrm{lbs}$.) of beans, peas or any large sized seeds.

When used for the smaller seeds, such as alfalfa and clover a 1-acre package should be used for each 15 lbs. of seed.

For Vetch use a 1-acre package for 20 lbs. of seed.

\section{Alfalfa in Standing Corn}

I am a great believer in Alfalfa as of course you know by this time, and also I am a believer in sowing it in standing corn, in July or August. I know that is against the rules of the game, but if it works who cares for the rules?

We all know that Alfalfa likes a well prepared, thoroly cultivated seed bed, and where would you get any better preparation than between the corn rows? We have been cultivating it and killing weeds all summer.

Of course it will need some moisture but it would need that anywhere, and we will hope that we will get it.

I have a field of sweet corn, Stowell's Evergreen, growing for seed. It is on just fairly good land. I am going to pick out the best ears in September and hang them up for seed, then turn in the hogs to hog down the rest.

I laid it by in the usual manner, then went through with a one horse cultivator to level it down between the rows, and then sowed alfalfa with a little sweet clover in it broadcast, and

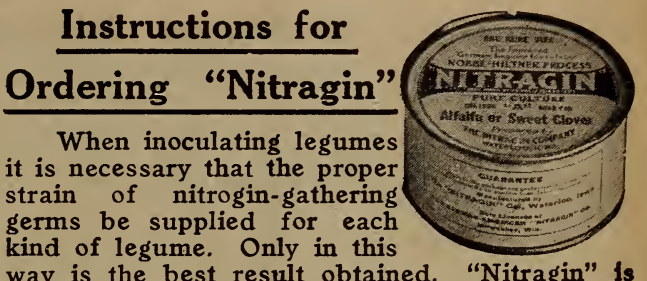
way is the best result obtained. "Nitragin" is furnished in special strains-the right ones for each legume.

To make it still easier for the farmer and dealer, we are now placing some of these strains in groups in one package. Thus Culture $A$ has both Alfalfa and Sweet Clover strains and can be used for both Alfalfa and Sweet Clover inoculation.

Or simply state the crop you want to plant and the correct culture will be sent to you.

You Can Now Order "Nitragin" as Follows: (These cutures are put up in $1 / 2,1$ and 5-acre sizes)

Alfalfa or Sweet Clover-_-_-_-_Culture A Clovers-Such as Red, Alsike, Crim-

son, White, Yellow, etc Garden and Field Peas or All Vet-

ches -

Garden and Field Beans_-_-Culture D Soybeans_._-_._-_Special Soybean Culture Cowpeas_-_. Sweet Peas______Special Sweet Pea Culture W.e also furnish special "Nitragin" cultures for the following: Beggarweed; Fenugreek; Horsebeans; Lentils; Lupins; Peanuts; Sainfoin and Serradella.

(Cultures for less extensively used legumes furnished on application.)

$$
\text { Prices of "Nitragin": }
$$

Garden size - 30

(For peas, beans and sweet peas)

$1-2$ acre size

1 -acre size -

5-acre size -

Postage, express or freight charges extra.

let the rain wash it in. We have already had a good shower, and it is coming fine. 'The hogs may kill it out some in hogging down the corn this fall, but I figure it will be so big by that time, that it will not hurt moch. The hogs will be after the corn anyway.

On part of the piece I am also drilling rye with a one horse wheat drill, between the corn rows right after I sow the alfalfa. This is for winter and spring hog pasture, and if the hogs do not keep it down in the spring I will cut it for hay about June 1st and then let the alfalfa take it.

You see I am figuring on lots of hog pasture. and while I may lose out, I don't believe I will. Anyway, if I get a fair amount of rain I will get enough good out of the fall pasture and the winter cover on the ground to pay me for $\mathrm{my}$ work and seed, and whatever I get for next year will be clear gain. And there is no chance to lose a year's use of the land either.

Now this plan may not look good to you, and it may not be worth trying under your conditions, but I am passing along the information for what it is worth. 


\section{A Page About Inoculation}

After a good many years of experimenting and observation I am convinced that the legume crops such as alfalfa, clover, soy beans and sweet clover, need inoculation more than we suspect.

Here in Southwest Iowa, where such crops are fairly easy to start we have always been quite successful, either with or without inoculation, and I did have the notion for awhile that it was not necessary here.

I have changed my opinion now. It may not be absolutely necessary in all cases here, but it is at least beneficial in practically all cases, and really necessary in many. It don't cost much, don't do any harm, and may do a great deal of good.

\section{How to Get Inoculation}

Admitting that it is a good thing and very near a necessity, the next question is how to get in the best, cheapest, most convenient and most practical way.

One way is to haul dirt from an old field that is growing a successful crop of the plant we wish to grow. That is all right, but it is lots of work not always available, and may bring in weed seeds.

The modern way, the one advocated now by all the state colleges and experiment stations, is to use the so-called "pure cultures" or what is commonly known as "canned bacteria."

These are cultures of the proper kind of bacteria, kept pure and strong, and propagated in some suitable material for growing and shipping them. They were first prepared and put out by the U. S. Department of Agriculture and the State Colleges, and are now being put out in a commercial way by a number of firms. They comply with the Govt. rules and methods and put out a reliable and practical product.

There are two different fillers or carriers used for growing and shipping the bacteria. One is the jelly, gelatin, or agar, which looks like thick soup stock, and comes in bottles. The other is a special sort of moist granular peat, and comes in flat tin cans.

When I decided to handle the commercial inocular I looked into it closely and decided that the best ones were the Standard and Nitragin. The Standard is a gelatin preparation, the Nitragin uses peat. You can pay your money and take your choice. Both are fully guaranteed both by the makers and ourselves.

We carry a full supply of both on hand here at Shenandoah, and can fix you out in good shape and promptly. The cost is very much the same.

You will find on the next page an advertisement of each one. I will be glad to have your order for either one.

\section{What Crops to Use It On}

Inoculation is used only on legumes-that is plants which bear their seeds in pods. Under the head of legumes are included Alfalfa, Sweet Clover, Soys, Cow Peas, all Beans and
Peas, all the Clovers, Vetch, Lespedeza, Peanuts, and many other crops.

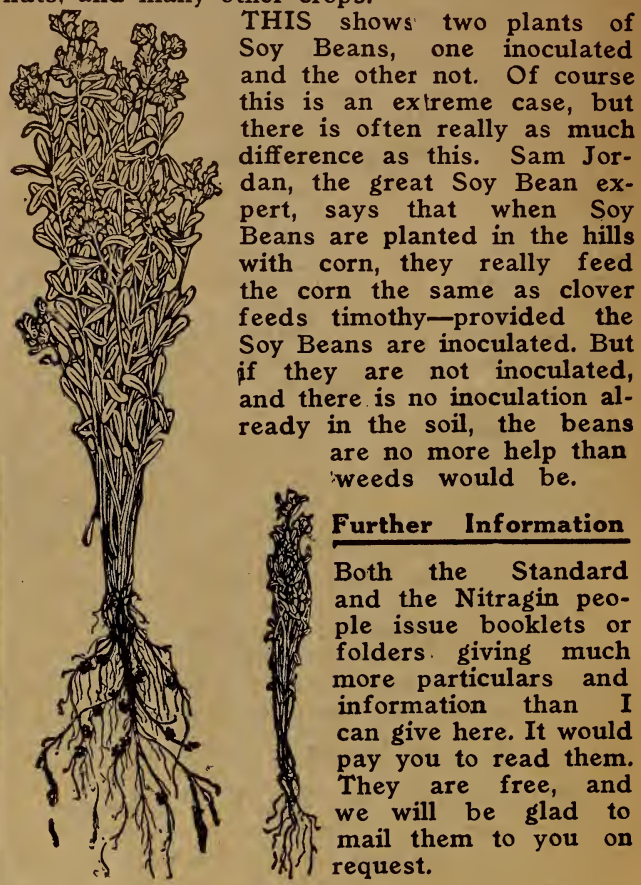

\section{Benefits of Inoculation}

The principal reasons for inoculation can be stated in five short paragraphs, viz:

First:-Inoculated legumes take nitrogin from the air to supply the plant, resulting in faster growth, earlier maturity and larger crops.

Second:-Inoculated legumes take up more nitrogin than the plant itself requires, the surplus insuring to the benefit of future crops.

Third :-Inoculated legumes develop larger root systems than not inoculated and therefore reach the immense stores of potash and phosphorous in the soil, bringing them up to supply the plant. When the roots and stubble decay, these elements are returned to the soil, in a form available to future crops.

Fourth:-Inoculated legumes, in taking their nitrogin from the air, save the soil. When not inoculated they drain the soil of its nitrogin just the same as wheat or timothy or other non-leguminous plants.

Fifth:-Inoculated legumes contain more proteid matter than when not inoculated, greatly increasing their feeding value.

Summary.-Inoculation hastens maturity, increases the crop, improves its quality, enriches the soil and saves fertilizer bills. 


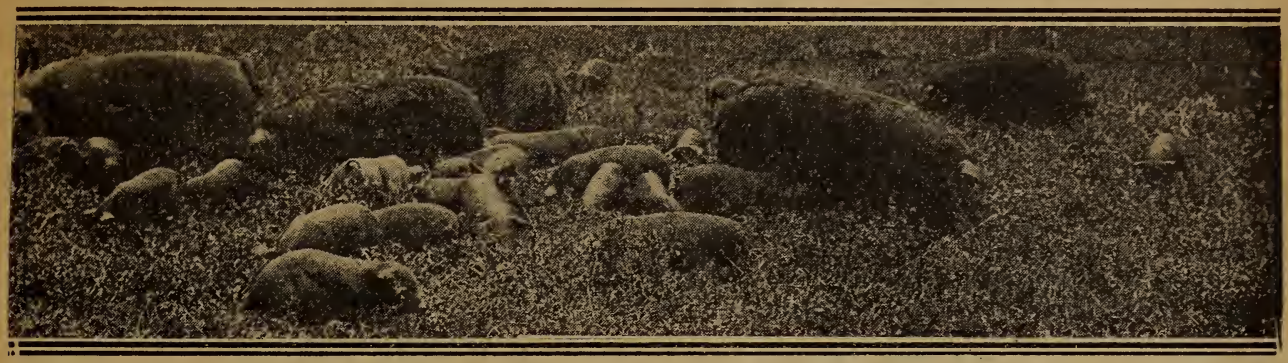

\section{Alfalfa and Hogs}

If I were raising hogs for a living I would have alfalfa for them or else I'd move to where I could have it. There is no feed on earth that will make as much pork, or as good pork, or make it quicker, or with so little work and risk and trouble, as alfalfa. Hogs and alfalfa just naturally dovetail in together better than any combination I ever saw. Hogs raised on alfalfa don't have cholera. Now hold on, brother, don't call me a liar till you've tried it and see. I've watched it pretty close and I have never found a case of cholera among hogs pastured on al. falfa, and kept away from too much corn.

Careful tests and experiments show that sows kept on alfalfa pasture, and alfalfa hay, average two or three more pigs to the litter (grown to maturity) give 30 per cent more milk, and the pigs at 3 months old are 25 per cent to 30 per cent bigger than pigs grown by any other method. The bone and muscle are so much better developed that alfalfa hogs never break down in fattening and shipping.

The finest and highest priced hams and bacon in the market are made from hogs grown on alfalfa and finished with just a little corn.

The Nebraska State Experiment Station, after careful tests, announced that hogs fattened on alfalfa hay and corn put on gain at a cost of $\$ 3.40$ per 100 lbs., while hogs on corn alone put on gain at $\$ 4.48$ per 100 lbs.

The Iowa State Experiment Station reports that 1 acre of alfalfa is worth more than 3 acres of blue grass pig pasture.

The Kansas State Experiment Station reports that a bunch of hogs fed on corn and alfalfa made 90.9 lbs. gain per hog in 10 weeks, while an exactly similar bunch fed on corn alone made 52.4 lbs. gain per hog in 10 weeks. In both cases the hogs had all the corn they would eat, but the one bunch had the alfalfa in addition. They add: "These results are not due to the feeding value of the alfalfa alone, but also to it's influence in aiding the hogs to better digest the corn."

I could go on this way forever, but what's the use? If you're determined to keep on growing hogs on corn and cholera I suppose you'll have to be allowed to do it. But just the same when I retire from the seed business I'm going to have the niftiest little bunch of hogs you ever saw, and they'd be raised on alfalfa and about one-fourth ration of corn.

Don't pasture your hogs on the alfalfa till it gets well established, say a year old or more, and don't put over 5 big hogs or 20 shoats to the acre then, it shouldn't be pastured too close.
The Gospel of Alfalfa

I want to warn you right now that if you get me started talking alfalfa I'm not going to stop till I run out of paper. It's pretty near a religion with me, this alfalfa business, and for a good many years I've been doing more missionary work for alfalfa than for the heathen.

The neighbors say I am crazy about alfalfa, and maybe I am, but it's a good bit like it was with one good brother here years ago, who went to a camp meeting and got full of the real old. time religion, the kind they used to have when you and I were boys. In fact, he got more religion than he could hold, and it set him to jumping and shouting, he was so happy.

It was rumored to him that the neighbors said he was crazy. "Well," he said, "if I'm crazy, it's a mighty good kind of crazy anyway." And that's the way I feel about this alfalfa business. And I'm going to keep on shouting about it. If you don't get alfalfa it won't be my fault.

Now, I know lots of you have heard that it's hard to start, and that it isn't suited to your land, and that you've got to inoculate and do this and that, until you get to going around in circles and scared to death about it.

\section{How to Get Good Alfalfa Seed}

Coburn says: "Success cannot come except when good seed is used. Much of that on the market, especially imported seed, has been adulterated or is so mixed with weed seeds that it would be dear as a gift."

He didn't make it a bit too strong, either. I have seen samples of alfalfa seed that would be ten dollars an acre damage to a man if he got it for nothing. Full of dodder, buckhorn, dock, lambsquarter and the Lord only knows what. Don't touch it.

You don't have to buy that kind of seed. Get yourself one of these old-fashioned threelegged microscopes that sell for one dollar and examine closely every sample of seed offered you. If you see anything suspicious in it leare it alone. You can get the good seed if you insist on it.

I handle the best possible grade of seed and sell it subject to approval. I get it direct from the growers in the best localities-no imported seed in mine. I ship it on the understanding that you can put it to any test you wish and if not satisfactory you can return it at my expense and have your money back. Now, if you want any better proposition than that, write it yourself. 


\section{The Sudan Grass Is Looking Fine}

This is our fifth year growing Sudan grass in large fields, and the more I see of it the better I like it. Year before last we had a chance to try it in dry weather and last year in wet weather. One was about as extreme as the other. I never saw a crop that seemed to be so nearly independent of the weather.

As we want to get all the seed we can, and do not care specially for feed, we are not going to cut it till about frost, but let it stand and make all the seed it will, then cut and bind it, head it, save the fodder, and thresh the heads. It was planted in rows at the rate of $21 / 2 \mathrm{lbs}$. per acre. You can't see the rows now though, It is so thick.

One good thing about it, it never lodges or foes down. Last summer has been a good test of that. The wet weather made rapid soft growth, and it was tall and slender, and we had several severe storms of wind and rain that put small grain flat on the ground, and would have put thick cane down the same way, but the Sudan stands up as straight as ever.

I think that as the seed gets cheaper a great many farmers will sow it broadcast or put it in with a wheat drill and harvest it with a grain binder, either for hay or seed. So in order to fet a line on this way of handling it, we put in a small field of it broadcast at the rate of 40 lbs. of seed per acte, on May 15th. For comparison we sowed right next to it the same amount of German millet, using the same amount of seed, $40 \mathrm{lbs}$. per acre.

The Sudan is making by far the best showIng. I was surprised to see it do so well broadcast. It is very heavy and thrifty and would make an enormous cutting of hay. At this writing, July 15th, it is about $5 \mathrm{ft}$. high and beginning to head. It is just right now to cut for hay. The millet is less than $4 \mathrm{ft}$. high and would not make over half the yield the Sudan would. Besides the Sudan would be by far the best feed. The Sudan is heading the earliest of the two.

I am more than ever of the opinion that Sudan has come to stay. There is no excuse whatever for growing millet any more, nor fodder cane. Sudan is by far better than either, in every way. Better yield, earlier, and better feed. Easier grown, easier cured, and better liked by stock. And the seed will be cheap enough hereafter, so that it will be no more expensive to use. It will be the ideal crop for the renter or small land owner who wants a quick and certain hay crop of good quality and heavy yield. And for a catch crop it is ideal.

\section{A Great Time to Sow Alfalfa}

It's the best time to sow alfalfa seed I ever aw. We are selling three times as much alfalfa seed as we ever sold before. Partly because of big demand and partly because our price and quality are right.

If you. are thinking of sowing, alfalfa-and you sure ought to be-now is the time to get busy. There is still time to get it started this fall, and you never will have a better chance We can make rush shipment of the seed.

\section{"Loyalty"}

If you work for a man, in heaven's name work for him. If he pays wages that supply you your bread and butter, work for him, speak well of him, think well of him, stand by him, and stand by the institution he represents. I think if I worked for a man, I would work for him. I would not work for him a part of his time, but all of his time. I would give an undivided service or none. If put to a pinch, an ounce of loyalty is worth a pound of cleverness. If you must villify, condemn and ternally disparage, why, resign your postion, and when you are outside, damn to your heart's content. But, I pray you, so long as you are a part of an institution, do not condemn it. Not that you will injure the institution-but when you disparage the concern of which you are a part vou disparage yourself. And don't forget-'I Forgot' won't do in business." Fra Elbertus.

\section{$\$ 8.00$ Alfalfa Seed}

Ordinarily, we do not offer but one grade of seed, that to be the very highest fancy grade obtainable. However, in buying big lots of seeds, as we do, we very often have to take a few sacks of second grade seed in order to get the rest. Ordinarily we dump this seed on some wholesaler for whatever it will bring, but we have a few sacks of it on hand now that is really too good to sacrifice. It is not first class, but on the other hand it is good value at a price of say $\$ 10.00$ per bushel. The seed is a little off in color and contains some weed seed, but nothing dangerous.

If you want a bargain in low-priced alfalfa seed, send for some of this $\$ 8.00$ seed.

\section{Why Run the Breweries?}

"Why should the German breweries in this good old U.S. of ours be allowed to run and use more than $64,000,000$ bushels of grain and us go without same for bread?

We are asked to raise more poultry and $I$ have five times as much as last year and now can't buy feed for them.

I think that all breweries should be closed, and should there be any owned by a good American I think he would close without being asked.

What the $U$ boats destroy is not a drop in a bucket to compare with the brewery. I think it's time the American people are stirred to the very limit. I think if Hoover had the say in less than 24 hours all breweries would be closed and grain turned to the government. The U.S. is at war with Germany yet we seem to not think of all that is being done here at home to use our grain to make liquors to destroy the homes and lives of our boys.

Government figures show that there is enough money spent for liquor each year to feed two million soldiers and have enough left to build another Panama Canal, and yet the breweries are allowed to carry on this waste, and we are all asked to saive and go without. Yours truly;" 


\section{The Alfalfa Seed Situation}

I don't remember a time since I have been in the seed business when the situation on alfalfa seed prices was as strong as it is right now. The crop of seed last year was comparatively light and the war shut off all imports, while on the other hand the demand for seed was much greater than usual. On top of that, the outlook for the new crop is not at all promising.

The wholesale market on alfalfa seed has been strong all spring and during the last two weeks has advanced $\$ 1.00$ per 100 lbs. with a prospect for further advances right along as the seeding demand increases.

We foresaw these conditions last spring and put all of our surplus money into alfalfa seed. We were buying seed all spring wherever we could get it of high quality and purity. The supply of the kind of seed we want is never large and we hunted the United States over to get all we could of first-class seed and we managed to accumulate about 1,000 bags, or say, 2,500 bushels. I think very likely this is the largest lot of first-class alfalfa seed held by anyone in the United States at this time. It is Kansas, Nebraska, South Dakota and Montana seed, all of very high color and almost perfect purity. It is new crop, dry-land grown and just the kind of alfalfa you would want.

The question with us now is what to do about the price. In the present state of the market we would be justified in advancing our prices at least one dollar per bushel, but on the other hand we can make a fair profit on what the seed cost us by selling it at the prices in the price list.

After puzzling over it considerable we have decided to leave our prices at this figure, make a fair profit, and let our customers have the benefit of the advance in the market.

This is possibly a difference of $\$ 2,500$ to us, for I really believe we could advance our prices $\$ 1.00$ per bushel and get away with it, but we are a little bit conservative and oldfashioned, and have the notion that a fair profit and good service to our customers are the proper things.

\section{Free Sample of Alfalfa}

I will send free to any one, a small sample of alfalfa seed for testing. Send it to your experiment station and ask them if it is good; if it has dodder or any other bad weed in it; if it is good, bright, sound seed that will grow.

An eastern experiment station bought seeds from a dozen different seed houses and tested it; they reported that mine was the best and only one they would care to plant for their own use. Small sample, free. Large sample, (several ounces) $10 c$.

I am willing to have my alfalfa seed put to any test you want-examine it yourself, let your neighbors look it over, send it to your State experiment station if you want to. If the seed isn't right I don't want you to keep it-send it back at my expense.

\section{Now Is the Time to Sow Alfalfa}

There is a great deal of dispute as to when is the best time to sow alfalfa, but I believe the majority of the farmers, especially here in the central west, have the best success sowing it in August.

If the ground is in the right condition, the seed will start very quickly, and you will not be bothered with weeds as you would in the spring. The alfalfa will make fine growth yet this fall. It is not likely that you will get enough top growth to cut for hay yet this fall, but it will be in fine shape to make a big crop next year.

Any time during August or the first part of September is all right to sow the seed, just whenever your land is in the right shape. Work it till it is fine and mellow on top, and free from trash, and weeds. It does not like freshly plowed land. It should have a chance to settle first. Generally it should not be sown till two or three weeks after the ground is plowed, and longer is better.

As to seed my advice would be to use anywhere from 15 to $20 \mathrm{lbs}$. per acre. If the seed is good and is put in the ground and covered up so it has a chance to grow, that amount is plenty, or more than plenty.

Of course you want the best you can get and that is the kind we have. All our seed is guaranteed satisfactory or no pay. It is sold subject to your own test and approval and subject to the test and approval of any State College or Experiment Station. I will be glad to send you sample for examination. See the last page of this issue for prices.

\section{Alfalfa Following Oats}

I suppose three hundred different people have written me in the last month or six weeks asking about putting in alfalfa on oats ground after the oats have been cut.

Now, it is just possible you can make it work. I have known it to be a success and I have known it about as many times to be a flat failure. It depends some on the soil and more on the season. The trouble is the oats pull, the moisture out of the ground pretty fast and the chances are that after the oats are cut the ground will be so dry and hard that it will be a mighty hard proposition to get it worked up into nice shape for sowing alfalfa. You must remember that alfalfa absolutely must have the ground in good condition.

If you really feel that you must put alfalfa in following oats, I would suggest that you follow the binder with a disc and chop the ground up thoroughly by running both ways. Then plow immediately if the ground is in condition so it can be plowed, and disc and harrow it several times again. Then, after about a month disc and harrow at intervals to keep ground loose, weeds killed, and moisture from escaping.

This would throw you to the middle of August, which is a good time to sow alfalfa. If the weather has been good and you have done thorough, careful work, the chances are good for a good stand of alfalfa but I really believe it would be better to put the alfalfa on ground which has not grown a crop this year at all. 


\section{Out of the Letter Basket}

\section{"Wants a Goat"}

"No sir, I am not going to send you a picture of my wife for "Seed Sense" cos why, she thinks you are the only man around that really 18. Well that is all right I won't say that.

She sent to you and bought a dozen Everbearing strawberry plants to show me that strawberries were some good and now I have been hunting the country over for a milk goat and she said, 'You write Henry and he will tell you where you can get one.'

I don't care I had to fess up an order 100 plants and we now have $a$ fine bed and the neighbors are all watching and commenting how nice they are. I am expecting they will take mighty well next week when they will be full bearing. Yours,"-F. B. Millard, Toledo, Ia.

\section{"Likes Sudan Grass"}

"Dear Sir: I write to tell you about Sudan Grass. It was planted in April in 12 inch drills and it is now May 1st 6 feet high and the best grass I ever saw of any kind. I thank you for introducing it to me. I shall never do without It as long as I deal in grass.

Now will you give a little advice? At what time should I cut it, after or before the seed is ripe? I am showing it to everyone that comes by. Grass is now coming to a head.

Hoping to hear from you soon, I am as ever yours for the best Sudan in Texas,".

-W. M. Viney, 722 Girard St., Houston, Tex.

\section{Soy Bean Flour for Cookies}

"Dear Sir: I want to say that you cannot say too much in favor of Soy Beans. The flour Is a big help in this time of substitutes. I make bread, muffins, cake and cookies with it, using from 1-3 to 2-3 and sometimes more of it.

The next time I make cookies I will send you a sample. Yours truly,"

-Mrs. Emma A. Stahl, Osceola, Ia.

\section{"Enjoys Planting Field's Seeds"}

"I am now sending you an order for 60c again and I have ordered nearly $\$ 2.00$ worth before from you this season so I will be looking for 'Seed Sense' regular each month now and thanks in advance.

$I$ am so well pleased with your seeds I send almost all of my time planting them and cultivating the ground for them.

$I$ never did enjoy working in the garden so much as I have since I bought my seeds from you.

Last year you sent me some Yellow Beans In the Conglomeration Packet and I planted them and raised some which I am going to plant this year. Could you tell me what they are? I cannot find them in your catalog. They are the same size as the Kidney Bean, except they are bright yellow in color and they wind like pole beans.

Yours truly,"

-Mrs. M. M. Houton, Eagle Grove, Ia.

\section{Two Plants From Each Seed}

"I received your seeds and found them to be very satisfactory.

$I$ would have written you sooner, but on account of the shortage of time I didn't write before.

I wish to thank you for the flower seeds. I have planted some of them and they are coming up. The Red Seeded Casabas seemed to come up so thick that they make me believe two plants have come from each seed.

$I$ enclose herewith the names of two of my neighbors to whom I wish you would send a catalog, and I think they will buy seeds from you. Very truly,"

-S. Alfred Lushorty, Houston, Tex.

"Good Luck With Field's Seeds"

"I will send you an order for some melons. $I$ want you to send them to me at once.

Well, Mr. Field, I sure had good luck with your seeds.

My girl sold $\$ 15.00$ worth for you this spring.

The White Elephant corn made a big yield last year, but as I got it in late the frost got it.

I have a fine garden this year. Saved my seeds mostly.

Well, I think everybody ought to trade with Field for $a$ square deal and good seeds, so thanking you and asking you to rush this order. I remain,"-Lewis Day, Ellston, Ia.

\section{Cows and Calves Like Sudan}

"Mr. Henry Field: I will plant a little more Sudan this year and try it on another field as my stock all like it so well especially the cows and calves. The latter would hardly leave the green Sudan to drink milk and as soon as they were done with the milk would just run back to the Sudan. My stock all like it better than anything except alfalfa and some like it better than even alfalfa. Not much Sudan has been planted around here. Respectfully," -J. N. Oates, Fayetteville, Ark.

\section{No Fly Specks on Our Packages}

"Mr. Henry Field: I want to thank you for the prompt attention given to my order for bulbs, as I thought it would take some time to get them, and I, like many others, neglected sending for them, until late. I sent my order last Thursday evening, and I received the bulbs Monday noon, and was more than pleased. They are the BIGGEST, NICEST ones I ever saw. $I$ only expected small ones and there were three big Dahlia roots in one clump. I didn't know whether to separate them or not, but a neighbor told me to do so, and so I did. I set them out where passer-bys can see them when they bloom. I did not buy any seed this year for you sent such big packages last year that I had plenty to plant in my garden this spring. They are coming up in spite of the cold weather and there were no FLY SPECKS on the packets when I got them."-Mrs. Ed Bickford, Washington, Ia. 


\section{Out of the Letter Basket}

\section{Likes the Redhead}

"Dear Sir: Please send me your price on Redhead otmato plants. We tried one dozen of them last year and like them better than any other tomato we have ever seen. They bore splendidly and every one ripened before frost.

We have bought all our garden seeds from you for four seasons and have always been perfectly satisfied with them. We are always ready to recommend them to our friends.

Yours truly,"

-Thos. Garner, Bonaparte, Ia., Box 75

\section{Tepary Beans}

"I am a little late with my order, but on account of bad weather until May 1st we could not get ground in shape and will have only a small garden this year, but I want to tell you about one pound of Tepary Beans I bought of you last year.

Last season I bought one pound of your Tepary Beans for my brother who is a dry land farmer in Morrell County, Nebraska. He has sandy soil and he planted the Tepary Beans by themselves and used the same method of culture as for Navy Beans.

He said when all the other Beans on the place were wilted the Teparies stood up fresh and strong and when threshed he had 70 pounds of Teparies from one pound of seed. I do not know whether this would be called a fine yield or not, but I am more than satisfied with it.

I am using. Tepary Beans. We soak over night, par-boil in weak soda water, par-boil a second time in clear water, then cook or bake with pork same as Navy Beans.

Your seeds always grow. Best wishes to yourself and your grand family."

-Mrs. E. G. Weston, North Platte, Neb.

\section{Like the Seeds}

"Dear Sir: We received the garden seed Thursday, May 2nd. Just sent the order the first of the week. Now we are wondering how you got them here so quick. We were thinking we would have to wait a week any way but I guess we were mistaken. Yours truly,"

-Mrs. S. S. Maynard, Vinton, Ia.

\section{Speedy Service}

"Dear Sir: I did not have the opportunity of writing you sooner or I would have done so.

$I$ wish to congratulate you on the speedy service in filling orders, as $I$ received my order a good deal sooner than I expected it, and I certainly think I received my money's worth. Everything $I$ ordered was in fine condition. I appreciate the complimentary packets of seed very much and think they are immense.

Wishing you the best of success for a prosperous year and hoping I may have the pleasure of hearing from you, I am,

Very truly yours,"

-Geo. A. Oswald, 3303 S. Oakley, Chicago, Ill.

\section{A Lifelong Customer}

"I have been buying seeds from you for several years and thought it my duty to write and tell you that I have saved enough seed from last year that I won't have to send for any this year.

I have Winter Cabbage and Collards, set out to raise seed for next year.

I want to praise your seed to the whole garden raisers as they are the best and come up better than any $I$ ever bought.

The radishes just beat anything I ever saw. They were as large as turnips.

I missed Ruth, Georgia and John Henry in this last 'Seed Sense'. I always like to see their smiling faces.

$I$ remain a lifelong customer,"

-Mrs. J. S. Pinkley, Raleigh, Tenn. Rt. 2

\section{Rag Weeds for Cabbage Worms}

"Dear Sir: Your catalog received but have home raised seed this year. I note what you say about cabbage worms and pass on a remedy given me last year by an old farm woman. Break green rag weeds and cover the tops of the cabbage, let stay till dry and repeat if necessary. This worked to perfection for me last year when all other remedies failed. Yours truly,"

-Mrs. Lem D. Faver, Tallapoosa, Ga.

\section{Found Seeds to Be First Class}

"Dear Mr. Field: Received our garden seeds some time ago and found them on arrival to be first class and surely grand seeds.

$I$ also received the Sweet Pea seeds and wish to thank you very kindly for the information you gave me in regard to them. Yours truly." -Mrs. S R. Woolf, Council Grove, Kans.

\section{Nursery Stock Well Packed}

"Dear Sir: It is almost impossible for me to refrain from expressing myself in my recent purchase of trees and shrubbery from you. They arrived very nicely packed, the roots in wet decomposed wood and roots thoroughly wrapped in heavy moist retainer paper securely wound and tied with small rope. Never have I seen nursery stock so thoroughly packed and every tree and bush are alive and doing. fine. I am mure than well pleased with the goods and your promptness and methods of business. Shall be pleased to give you other orders for goods and am sure you will receive orders from $m y$ friends. Very truly yours,"

-Col. Julius C. Timson.

\section{Good Plants and Onion Sets}

Dear Sir: I thank you for the nice trees and plants just received from you. All are plant. ed and are living. I am more than pleased with them, and am recommending you to all my neighbors.

The onion sets bought from you are fine. Yours sincerely,"

-Mrs. Annie Burchell, Rossmoyne, 0. 


\section{Flags}

All Kinds at Very Lowest Prices

America is sending her best men to fight for freedom and in their honor the whole land is dotted with Service Flags carrying the stars of sacrifice.

The Sars and Stripes is the emblem which unites us in war for human liberty and national honor.

The Service Flag is the emblem which unites us in mutual sympathy for the men who give themselves and for those who give their men. These flags inspire all citizens to greater patriotism and greater sacrifice.

During the past year we have sold thousands of flags and we are selling more every month, but prices are continually advancing.

We have been forced to increase some of our flags but have held the price down as much as possible. Material is scarce and labor high. Prices will probably advance again soon. Compare our prices with those of other concerns and you will see that we are still extremely low in price.

If you intend buying a flag of any description, place your order now.

\section{Our Prices}

Old Glory" made of medium weight cotten material, sewed stripes, printed stars, well made in every respect, with eyelets in corners for attaching ropes. The flags are not mounted, neither do we furnish staffs or poles. Fast colors.

Size $3 \times 5 \mathrm{ft}$, as described above $\$ 1.50$ postpaid

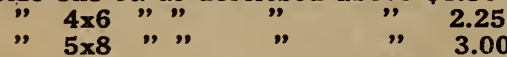

"Boy Scout" Flag Outfits, made of good quality cotton printed stars and stripes, fast colors, mounted on a 5 foot, double jointed, polished staff, with a gilt spear head. Just the thing for parades and decorative purposes where a large flag cannot be used. Each flag packed in a separate box.

\section{A Hog Story}

Is it possible to make ordinary grade shotes weigh $300 \mathrm{lbs}$. at $81 / 2$ months old?

Some say it can be done, and some say it can't. I don't know, but I a mtrying to find out by actual experience.

I bought two old red sows at a sale in March, and the first week of April they had 11 one pig to a man working for me and have 21 pigs apiece and saved every one. I gave away left. I want to sell them about Dec. 15th to 20 th, and I want them to average 300 and sell for $\$ 1,000$. I really believe they are going to do it. At this writing, July 8th, they are a few days over 3 months and weigh right at $100 \mathrm{lbs}$. apiece. And they are growing like bad weeds. They are on Alfalfa pasture, and have a self feeder with three compartments in it-tankage, corn and mill feed. They have never been hungry in their lives, started on bluegrass, mill feed and Alfalfa hay, and went onto Alfalfa pasture at 8 weeks old. They will hog down corn in
Single outfit, price $\$ 1.25$ postpaid. Dozen lots $\$ 1.00$ each, postpaid.

Small Silk "Stars and Stripes" mounted on black sticks with a small gilt spear head. Good quality Shappe silk. Just the thing for automobiles, motor cycles, etc.

$8 \times 10$ inch size, $25 \mathrm{c}$ each postpaid. Dozen lots, 20 c each postpaid.

$10 \times 15$ inch size, $30 \mathrm{c}$ each postpaid, Dozen lots, 25c each, postpaid.

Service Flags, cotton material, good quality, fast colors, sewed on stars, with eyelets in corners of flag for fastening to ropes.

Size $12 \times 18$ inch. Price 50 each postpaid. Dozen lots $40 \mathrm{c}$ each postpaid.

Size $2 \times 3$ feet. Price $\$ 1.25$ each postpaid. Dozen lots $\$ 1.00$ each postpaid.

Size $3 \times 5$ feet. Price 61.75 each postpaid. Dozen lots $\$ 1.50$ each postpaid.

Silk Service Flags. Very best flag, silk, and mounted on sticks with spear head on each side. Flag is trimmed with gold fringe, and hung by a gold cord with tassels at each end. The most beautiful service flag on the market today.

Size $12 \times 18$ inches. 1,2 or 3 stars___ $\$ 2.50$ $8 \times 12 " 1,2$ or $3 "$

Extra stars $10 \mathrm{c}$ per pair. Larger size silk flags made to order. Write for prices.

Wool Flags. We can supply wool flags in either service flags or national flags. We also make flags of Sampson Bunting which will wear longer than wool and looks about as rich. Tell us the kind and size of flags you want and we will quote prices.

Let us figure on a service flag for your town, church, lodge or other organization. We can save you money.

\section{Our Guarantee}

Every article we offer is guaranteed as represented. All goods are sent subject to your own inspection and approval, and if not perfectly satisfactory they should be returned promptly and your money will be cheerfully refunded. You run no risk in buying of us.

September, October and November.

Will they make it? What do you think? If they do it, can it be done on a larger scale next year? Would you change the feed I am giving them? Write and let me know.

No, I am not afraid of cholera. I have vaccinated them, double treatment, and they are nicely over it some time ago.

Yes, I will let you know how they come out, what they weigh, how much grain they ate, and what it cost.

H. F.

\section{"Third Order This Season"}

"I am coming with my third order. You may think I am insane and I will not deny the charge. My wife says she does not like your seeds because every seed makes about 5 plants and she has to do so much thinning.

$P$. S. Could we harvest the Rose Winter radish with a stump puller when one has rocky ground?"

-Elza Buxton, Rt. 2, Neosho, Mo. 